\title{
Dialectical logic or logical dialectics? The Polish discussion on the principle of non-contradiction (1946-1957)
}

\author{
Monika Woźniak ${ }^{1}$ (10
}

Accepted: 23 September 2021 / Published online: 26 November 2021

(c) The Author(s) 2021

\begin{abstract}
The discussion on the principle of non-contradiction (1946-1957) between Marxist and non-Marxist philosophers was one of the major philosophical discussions in Polish philosophy of this period. In my text, I carefully reconstruct this discussion and outline its relation to Soviet debates on the subject. I show that the change in Schaff's position happened in the early 1950s under the combined influence of the Lvov-Warsaw School and the changes in the official Soviet position regarding formal logic. I discuss the aftermath following Schaff's change in attitude towards the analytic tradition for the development of Polish philosophy, as well as the critique of this change by Jarosław Ładosz. In my reconstruction of the latter, I focus on the problem of the historical development of science. I refer to Ilyenkov's critique of Schaff, opposing synchronic ("positivist") and diachronic ("dialectical") concepts of knowledge. As I argue, these opposing concepts of science can be seen as a genuine issue at stake in the Polish discussion as well, especially in the polemic between Schaff and Ładosz.
\end{abstract}

Keywords Polish marxism · Dialectical logic · Logic in the USSR · Adam Schaff · Jarosław Ładosz

\footnotetext{
This essay grew out of a paper presented at the meeting of Education and Philosophy in the Conversation research group at Queen's University, Kingston, Canada in 2019; an early version was presented at the seminar organized by the Department for the Study of Modern Czech Philosophy and "Contradictions: A Journal for Critical Thought," I am grateful to all participants of those events for their feedback. I am especially grateful to David Bakhurst, Ivan Landa, and Jan Mervart for organizing these events and for their helpful comments on different versions of the text.
}

Monika Woźniak

mon.m.wozniak@gmail.com

1 University of Wrocław, Wrocław, Poland 


\section{Introduction}

The discussion on the principle of non-contradiction in Poland took place between the years 1946 and $1957^{1}$ and was one of the major philosophical discussions in Polish philosophy in that period. It was initiated by Adam Schaff in 1946 and for 11 years engaged both Marxist and non-Marxist philosophers: Adam Schaff, Kazimierz Ajdukiewicz, Helena Eilstein, Stanisław Ossowski, Waldemar Rolbiecki, Jarosław Ładosz and Maria Kokoszyńska. Although the discussion has been described by scholars in the past, most notably Lobkowicz (1961), Jordan (1963, pp. 263-313) and Nowaczyk (1967), this was often done from positions favourable to the analytic tradition and rather distant from Marxism. This can be clearly seen in the case of Jordan, who was associated with the Lvov-Warsaw School and considered the Hegelian and Marxist tradition of thinking about contradiction to be simply absurd. This often led to describing the victory of the opponents of dialectical contradiction as something natural - a simple return to a healthy situation in philosophy after the period of Stalinist ideological pressure. Going beyond this narrative, however, enables the differences between different Marxist authors and their positions in the debate to become more visible (especially concerning science and historicity). Moreover, it helps in determining the specific factors that contributed to the rejection of dialectical logic.

I divide the reconstruction of the discussion into two parts. The first one begins with Schaff's proclamation of the superiority of dialectical over formal logic ${ }^{2}$ in 1946. I follow the critique of that position by Stanisław Ossowski and Kazimierz Ajdukiewicz, and analyze Schaff's change of position in the text from 1955. I show this shift took place before 1955 and was influenced by discussions on formal logic in the Soviet Union. The second part of the text begins with Jarosław Ładosz's critique of Schaff's new position. I focus on Ładosz's account of the role of contradiction in the history of science-a position, to a certain degree, also shared by Waldemar Rolbiecki. I reconstruct the critique of that position that can be found in the works of Helena Eilstein and Maria Kokoszyńska, who also criticized a Soviet opponent of Schaff, Mitrofan Alexeev. This reconstruction allows one to pose the question of the degree to which the supporters of "dialectical logic" shared a similar understanding of this concept.

\footnotetext{
1 Of course, the dialectic and its relation to formal logic were the object of many studies before and after (to name a few, Kłósak or Kokoszyńska); however, I treat the discussion as limited to the direct (although not linear) polemic that took place on the pages of Myśl Współczesna, Myśl Filozoficzna and Studia Filozoficzne.

2 I use the term "formal logic" as it was used in the debates of the period, that is, as a non-dialectical logic that abstracts from the content of analyzed structures. The participants of the Polish discussion tend to not distinguish between traditional and modern logic in their polemics, even though some of them developed this distinction elsewhere. The subject of the debate, that is the principle of contradiction, especially discussed in the context of Zeno's paradoxes or Hegel's critique of logic, did not encourage such distinctions. By "formal logic" they usually meant the standard textbook modern logic, understood, however, as something expanding on Aristotle or absorbing it rather than rejecting it (e.g. mentions of many-valued logic, although present, are rare).
} 
As mentioned above, the analyzed discussion in Poland was influenced by and sometimes reflected upon the Soviet debates on dialectical and formal logic that took place in the Soviet Union around the same time. ${ }^{3}$ It is therefore important to understand the general dynamic of the debates in Soviet Russia as well as the difference in the contexts of the Polish and Soviet discussions. In the Soviet Union, formal logic_-after a period of being viciously criticized as a bourgeois ideology in the 1930s - came back into favour in the 1940s with the support of Stalin, who felt the need to introduce the teaching of logic (Korsakov 2015, pp. 147-148). This return met with some difficulties and sharp polemics, as it could have been seen as, on the one hand, in line with Stalin's statements in Marxism and Problems of Linguistics, where Stalin announced the universal character of language, a line of thinking often used to argue for the analogous universal character of logic; and, on the other, irreconcilable with many statements of the Marxist classics (especially Engels and Lenin). The most orthodox position, expressed in the chapter on dialectical and historical materialism in History of the All-Union Communist Party (Bolsheviks): Short Course, was also not particularly clear on the subject; although it states the existence of inherent contradictions in nature, it also tends to describe it in terms of opposite forces or tendencies. Moreover, the Soviet discussion took place after Stalin's announcement of the end of the class struggle in the Soviet Union as well as in the period of rapid technological progress connected to developments in mathematical logic, both factors acting in favour of formal over dialectical logic. ${ }^{4}$ Nevertheless, in the 1950s, the situation was not set and could lean toward any side, which can be seen in the differences of emphasis in the editorials in Voprosy filosofii (cf. K itogam obsuzhdeniia voprosov logiki, 1951; Protiv putanitsy i vul'garizatsii v voprosakh logiki, 1955).

In Poland, on the other hand, the discussion of formal logic and dialectics started with the very beginning of the introduction of the new regime (its beginning, in fact, precedes the chronological framework of Polish Stalinism, which is thought to begin not earlier than 1948-49); it was not, therefore, a question of the re-installment of formal logic once the ideological hegemony of dialectical materialism was established and stable, but of establishing this hegemony in the first place. Until the year 1949, Marxism was forced to compete with Catholic philosophy, the Lvov-Warsaw School and phenomenology, the strongest currents in Polish pre-war philosophy

\footnotetext{
3 They were, however, mostly devoted to the object of formal and dialectical logic as well as the relationship between them; the specific problem of the principle of non-contradiction was discussed in Soviet philosophy only at the end of the 1950s, in 1958-1959 (Lobkowicz 1959:1).

4 These factors (among others) are discussed in M. Men'shikova's outstanding M.A. thesis (available at: https://nauchkor.ru/pubs/diskussii-o-dialekticheskoy-logike-v-sssr-5b6f41007966e1050a6e88e2), which remains the most thorough study of the social, political and institutional factors that allowed formal logic to triumph over dialectical logic. The key factor the author points to is the inability of dialectical logic to reproduce itself in education; it could be argued, however, that this should be treated as a symptom rather than the cause. The difficult position of dialectical logic in the Soviet Union, e.g. Ilyenkov's problems with censorship or Molodtsov's attempts to stop Mezhuev's scientific career (Beseda s V.M. Mezhuevym 2014), should in my opinion be seen as the result of competing not only with formal logic but also with the established institutional and philosophical position of official diamat, its main rival for the title of the leading Marxist philosophy.
} 
(Kojkoł 2009, p. 104; Stępień 1990, p. 22). The prestige and importance of the Lvov-Warsaw School were well established, on both a philosophical and an institutional level; Ajdukiewicz, for example, was the rector of Poznań University between 1948 and 1952 (Mackiewicz 2001, p. 138). Although at beginning of the 1950s the School became the object of ideological critique and its institutional role became limited (especially after the 1951 Congress of Polish Science), its influence on intellectual life remained enormous. Finally, despite the differences in the political situation, Polish Marxists had to consider the current state of Soviet philosophy.

\section{Towards universal validity of the principle of non-contradiction (1946-1955)}

The discussion about the principle of non-contradiction among Polish philosophers started immediately after the war and was initiated by Schaff's article "Zasada sprzeczności w świetle logiki dialektycznej" [The law of contradiction in light of dialectical logic] (1946). The text is an extensive polemic against the representatives of formal logic, which he associates with "common sense." In the article, Schaff claims that the contradiction is something ontological in nature-it takes place in reality, not solely in the judgement. Although Schaff is well aware of the difference between logical contradiction and polar opposites (which he labels as "contrasts"), he deliberately does not distinguish between them. The principal part of the argument is based on "confronting the rules of logic and the facts of experience" (Schaff 1946, p. 332). Schaff aims to demonstrate that the facts of experience show their contradictory nature, and therefore the description of them according to the principle of non-contradiction is invalid. He delineates three types of these facts: (1) phenomena of movement, becoming and change (where he emphasizes the Eleatic arguments against movement), (2) the mutual penetration of opposites, the transition between them and (3) "things and phenomena which involve an intrinsic contradiction" (Schaff 1946, p. 334). Under this enigmatic name, Schaff refers to the discoveries of modern physics (for example, the relation between mass and matter or de Broglie's theory).

His reasoning, however, is not supposed to lead to the rejection of formal logic, but to a "certain system of diarchy with dialectical logic at the forefront" (Schaff 1946, p. 353). Formal logic describes the world seen as something static, but it requires a dialectic to describe motion and change. The same argument-inspired by Engels' Anti-Dühring and used by Plekhanov-is also present in the first three editions of the Introduction to Marxist Theory (1946, 1947, 1948).

The idea of this "system of diarchy" was later opposed by Stanisław Ossowski, one of the most important Polish sociologists of a leftist (but not Marxist) orientation. In the years 1947 and 1948, Ossowski dedicated three texts to the rebirth of Marxism (Ossowski 1947, 1948a, 1948b). He argues that the opponents of the principle of non-contradiction display a dogmatic approach to Marxism, which is an obstacle to the development of Marxist theory. Marxism either works within the framework of formal logic or turns into a number of meaningless aphorisms. Dialectics conceptualizes movement in a specific way, but this conceptualization can be 
described in accordance with the laws of logic (Ossowski 1948a, p. 11). This element of Marxism understood as a scientific method or a way of understanding reality is characteristic for Ossowski, who rejects treating dialectics as a sum of aphorisms (generalized dogmas about the world). The main thrust of his critique is directed against Engels, Plekhanov and Schaff, who responded by echoing his arguments from 1946 (Schaff 1948). In his answer to that response, Ossowski emphasized that neither Marx's nor Lenin's reasoning in practical terms violates the principle of noncontradiction and that the entire issue has practical consequences. The concept of dialectical logic ("a legacy of idealistic German philosophy that still muddles also in the camp of the Left") opens the door to irrationalism and lack of responsibility for words (Ossowski 1948b, p. 32-33).

The most thorough critique of Schaff's arguments is presented by Kazimierz Ajdukiewicz in an article from 1948 which appeared in the journal Myśl Wspótczesna. Although he did not refer explicitly to Schaff's work, he devoted his text to the analysis of the arguments against the principle of non-contradiction. As one can imagine, Ajdukiewicz does not explicitly state his views on the relation between formal logic and dialectics; his only explicit aim is to examine the claims that change and movement involve a contradiction. The lack of such an explicit critique of Marxist fundaments can give the reader the idea of the limits of free discussion and the need to confront the ideas, proclaimed by the editorial board of Myśl Wspótczesna.

Ajdukiewicz argues against Zeno's paradoxes and against what he calls the "postulate of transition" (Ajdukiewicz 1948, p. 46), which is the claim that, during the process of changing from one state to another, there is a moment where both of the contradictory sentences are true. He also attacks the claim that assigning different characteristics to the same object at different points in time would necessarily lead to the rejection of the law of contradiction. Finally, he asserts that, when someone seems to both deny an attribute of an object and assign it-claiming, for example, that his father both is and is not "old"- that person does not violate the principle of non-contradiction, but simply cannot decide whether a certain predicate should be attributed to the object because of the vague character of the word.

The text presents an overview of existing solutions to Zeno's paradoxes offered by Aristotle, Bergson, and Reinach. The author claims that the origin of the paradoxes can be found in the vague meaning of terms such as "moment" and "being"; therefore, the seemingly contradictory character of movement can be eliminated by providing a precise definition of those terms. The other source of the paradoxes is the lack of a theory of infinite geometric series. Ajdukiewicz's argumentation is convincing, but the principle of contradiction can only be preserved at the cost of making the description of reality significantly more complex.

Schaff's response to Ajdukiewicz's argumentation must be called enthusiastic. In the article "Dialektyka marksistowska a zasada sprzeczności" [Marxist dialectics and the principle of contradiction], written in 1955, he abandons his previous claims altogether. There he agrees not only with Ajdukiewicz but also with Ossowski. He points to the ambiguity of the notion of contradiction; the one to blame for this state of affairs is Hegel, who Schaff criticized throughout his life (cf. Wiśniewski 2019). Instead, Schaff proposes to distinguish between the 
following instances of contradiction: (1) the logical contradiction, (2) the unity of opposites and (3) the inconsistency within a given system (this last example is illustrated by the contradiction of productive forces and relations of production). The contradiction as the unity of opposites and as an inconsistency do not violate the rules of formal logic. The only case which seems to do this is the contradictory character of movement in its Eleatic interpretation, his main argument from 1946. Schaff examines this once again with reference to Ajdukiewicz's arguments (and the excerpts from Bergson and Reinach which he uses); he focuses primarily on the ambivalent meaning of the copula "is."

Schaff's final aim is not, however, to reject dialectics for the sake of formal logic but to remove contradiction in the logical sense from dialectics. As he states:

We do not violate the essence of dialectics when we prove that considering reality to be changing does not lead to conflict with the logical principle of contradiction. On the contrary-we explicitly state that change is a certain unity and struggle of opposites. At the same time, only by respecting the logical law of contradiction can we understand and sensibly talk of the dialectical concept of change and development. (Schaff 1955, p. 158)

From that point forward, the claim that the analysis of language use can serve as a basis for solving philosophical disputes accompanies Schaff's works; we can see it, for example, in his most famous work, Marxism and the Human Individual. This was a big change, considering the fact that only three years earlier, in 1952, Schaff accused Ajdukiewicz of idealism and advocating for a doctrine leading to "conclusions that are regressive and allow for the defense of any kind of obscurantism and dilution of every real conflict in semantic speculations" (Schaff 1952, pp. 67-68).

Schaff accepted the universal validity of the non-contradiction principle even before 1955, which can be traced back to the revisions introduced into the fourth and fifth editions of Wstep do teorii marksizmu [Introduction to Theory of Marxism] in 1949 and 1950, where he abandons his previous views. He replaces them with cautious suggestions that the conflict between dialectics and formal logic appears only in the case of Engels' interpretation of motion-an interpretation deeply rooted in the development of mathematics in Engels' time-and that this problem "requires elaboration and thorough analysis" (Schaff 1950, p. 152). One year later, in his book $Z$ zagadnień marksistowskiej teorii prawdy [Selected Problems of Marxist Theory of Truth] from 1951, he openly states that "the principle of unity and struggle of opposites does not violate the validity of the logical non-contradiction principle in any way" (Schaff 1951, p. 87) and every theory that contains internal contradiction is wrong, while Marxism does not negate the laws of formal logic.

This shift in Schaff's views was clearly expressed right after the publication of Stalin's Marxism and Philosophy of Linguistics in 1950 and around the same time that the discussion on the relationship between formal logic and dialectics took place in Voprosy Filosofii (1950-1951). The discussion was concluded with the condemnation of Marxism (understood here as a theory denouncing formal logic as part of bourgeois ideological system), eclecticism (combining dialectical and formal logic as well as dialecticizing formal logic) and idealism (treating the laws of logic as 
laws of thought only, without reference to reality). The second part is of particular interest for us here. The editors state:

Formal logic is the science of elementary laws and forms of correct thinking. It is a set of elementary rules on how to use concepts, judgments, logical inference, so that our thinking is definite, coherent, consistent, evidence-based, non-contradictory. (...) There are no two formal logics: an old, metaphysical one, and new, dialectical one, just as there are no two-metaphysical and dialectical-arithmetic or grammar. There is one formal logic, universal for all people. (K itogam obsuzhdeniia voprosov logiki 1951, p. 146)

Dialectical logic, however, was not abandoned, but defined here as the epistemological theory of Marxism, identical to dialectics. Understood that way, dialectical logic is something higher than formal logic, which is elementary, and its superiority consists of two elements. Firstly, it does not only list the logical forms but can also relate them to each other, building the organic system where the higher form follows from the more elementary one; secondly, it is not formal, but links the laws of thinking to reality. Therefore, dialectical logic, which is a higher logic, does not supersede formal logic, but shows its limitedness ( $\mathrm{K}$ itogam obsuzhdeniia voprosov logiki 1951, p. 147). Formal logic is not enough for real knowledge; nevertheless, dialectical logic is not a different form of logic in the traditional sense of the word. Formal logic as a "set of elementary rules" is universal and classless. The editors suggest even collecting quotes from the classics, where they attack the inconsistent and contradictory character of the theories of their adversaries. The natural consequence of those claims seems to point to the conclusion that the principle of non-contradiction is universally valid; the text was used in exactly that way.

It is reasonable to assume that the rejection of the diarchy of the two logics in Schaff's views followed the changes that took place in the official Soviet philosophy of the time. It was, of course, also influenced by Ajdukiewicz. However, it was hardly the first harbinger of the end of the Stalinist repression of Polish philosophy, as it was sometimes described (Wolenski 1992, 98). This occurred not in 1955 but in 1951, when Schaff's efforts to conform to Stalinist dogmas and the party line were evident (cf. Czakon 1998). Even if Schaff was not familiar with the conclusion of the discussion before finishing the manuscript of The Selected Problems of Marxist Theory of Truth, he must have been aware of the general change of tone towards formal logic and especially of the consequences of Stalin's announcement of the universal character of language for logicians. As I would like to argue, this particular change should be interpreted as the effect of a combination of two factors: the shift in Soviet philosophy on the one hand, and the pressure of the influence of the Lvov-Warsaw School on the other-two factors that accidentally acted in the same direction. Of course, Schaff's text from 1955 can still be interpreted as a sign of the changing winds, ${ }^{5}$ but these changing winds should be traced rather in the

\footnotetext{
${ }^{5}$ The symptoms of philosophy's emancipation from Stalinist orthodoxy can be observed before the 20th Congress of the Communist Party in 1956 also in the case of Czechoslovakian philosophy (Mervart 2013, p. 10, footnote). The chronological frame of the Stalinist period in philosophy and the processes that led to forming and dissolving the unity between party line and philosophy deserve further research and detailed examination.
} 
general tone of revision (in 1951, Schaff does not signal any changes in his opinion on the subject) as well as the modification of his attitude towards semantic analysis and Ajdukiewicz's philosophy rather than in his recognition of the validity of the non-contradiction principle alone.

\section{The Marxist theory of knowledge and the contradiction in the development of science (1956-1957)}

Schaff's rejection of logical contradiction was criticized in 1956 by Jarosław Ładosz, Schaff's Ph.D. student. Ładosz graduated in mathematics and in the beginning of his academic career was interested mostly in logic and epistemology (Wielowartościowe rachunki zdań a rozwój logiki, 1961, Szkice z epistemologii matematyki: matematyka jako działalność konstruktywna, 1968). His later works are primarily devoted to the fundaments of Marxism and Marxism-Leninism. Andrzej Walicki, a person rather far from his beliefs, calls him "the last dogmatist, which clearly distinguished him from the eclectic and ideologically flexible conformists who call themselves Marxists" (Walicki 1997, p. 89).

Ładosz considers Schaff's new position a regress in comparison with his claims from 1946. He accuses Schaff of undermining the "cornerstone of materialist dialectics" (Ładosz 1956, p. 106) as a result of the influence of the Polish Neo-positivist tradition. He rejects, however, not only Schaff's program of removing logical contradictions from dialectics but also theories that aim to sanction the logical contradiction to construe a specific "logic of contradiction." Instead, he proposes interpreting the contradiction as the driving force of the development of knowledge that needs to be overcome rather than rejecting or sanctioning it. He sees the logical contradiction as something that plays not only a negative but also a positive role and accentuates the latter.

Consequently, the main part of his text is devoted to proving the role of logical contradiction in the history of scientific development and to the discussion of the question of contradiction of movement. While discussing the former issue, Ładosz characterizes scientific development as the process by which contradictions emerge and are overcome. Moreover, he argues that, at a certain stage of the development of the scientific theory, the two contradictory statements are-consciously or notregarded as true, even though they demand a resolution. The way to overcome them is not, however, to remove them through "semantic analysis," by pointing to the formal nuances of the terminology or by rejecting one of the statements. In the actual history of science, those solutions usually appear as the first stage of dealing with contradictions, but they cannot produce any real results. The contradiction has to be taken seriously, as having its origin in reality itself and revealing something about it, not simply rejected at once.

Contradictions of this type disappear with scientific development. Nevertheless, they should be considered not as something unwanted, but as something natural in the development of science as they are the driving force of this development as such. This is the crucial point in his polemics with Schaff: Ładosz is convinced that Schaff's approach towards contradictions-that is, the purely 
formal removal of the contradiction by way of finding a more nuanced description within the existing theory (rather than developing a new theory) - is, in fact, a barrier to understanding scientific development. It is a leap over the problem rather than a real solution to it. There is a certain stage in scientific development when a new theory has not yet been formulated and we must consider contradictory statements equally true, not escape from them (Ładosz 1956, p. 119, 123).

However, besides the type of contradictions which can be overcome, Ładosz also identifies a different type that he calls "everlasting contradiction" (Ładosz 1956 , p. 124). This is connected with the notion of movement. Ładosz admits that a non-contradictory description of movement is possible in classical mechanics, but argues that such a description only scratches the surface of the phenomenon of movement and its source. Despite their obvious limitations, Eleatic aporiae draw our attention to the eternal dialectic of continuity and discontinuity, of quantitative and qualitative changes, and the dialectics of the "material content of movement and the space-time form which this material content shapes and exceeds" (Ładosz 1956, p. 130). This, however, requires a creative analysis of the content of the aporiae in their depth rather than an automatic repetition of its original formulation. The same is true of change. Ajdukiewicz stays on the surface and describes the fact itself without asking about its cause, about the mechanism of change as such, whereas.

When we inquire into the cause of change, the charm of simplicity vanishes. We need to find the source of movement in state A itself, and we can only do it when we cease to understand it as something absolutely concrete. The concrete state $\mathrm{A}$ is reflected in our minds through notions, which are something general. Therefore, revealing any internal possibility of its movement has to result in a logical contradiction in its conceptual formulation. The supposed absolute concrete has to emerge only as a general formulation of something changing, the relative permanence of which was captured by the conceptual formulation. In order to overcome this logical contradiction, we should split the notion of the "state A," i.e., capture the regularities [prawidłowość] of the movement of this state through the use of new notions. (...) This is how the objective contradiction between the relative definiteness of moments in the material world ("states") and the change, the movement of this definiteness, is reflected in our cognition in notions. (Ładosz 1956, p. 131)

The quoted passage shows Ładosz's indebtedness to Lenin's Philosophical Notebooks. The concept of "splitting the notion of state A" alludes, of course, to Lenin's famous definition of dialectics as the splitting of unity. In the text "On the Question of Dialectics," Lenin writes.

The splitting of a single whole and the cognition of its contradictory parts (...) is the essence (one of the "essentials," one of the principal, if not the principal, characteristics or features) of dialectics. That is precisely how Hegel, too, puts the matter (...) The correctness of this aspect of the content of dialectics must be tested by the history of science. (Lenin 1972, 359) 
The emphasis on the history of science clearly shows the distance that separates Ładosz from the representatives of the official account of dialectical materialism (which is also evident in his preference for the term "materialist dialectics" rather than "dialectical materialism"). For him, dialectics is not a general theory of the development of reality - it is a method intrinsically linked to history. As he writes, "the laws of the nature cannot be understood without examining history and the current state of cognition, just as the laws of thought cannot be uncovered without the study of the world and practice" (Ładosz 1956, p. 114). Following Lenin, Ładosz objects to reducing dialectics to a "sum of examples." Instead, he suggests treating it as a method of ascending towards more complex conceptual schemes and systems through determining the source of emerged logical contradictions and understanding them. This brings him quite close to a later critic of Schaff's positivism, namely Evald Ilyenkov-a resemblance I discuss in the final part of this text.

According to Ładosz, "things" are not something absolute but are "blurred"they have no sharp borders and are subject to change. Treating notions as if they were sharp and accurate does not correspond to their nature or to the changing and moving nature of reality:

Notions, the basic form of our thought, capture-if they are true-relatively permanent "states" of the material world in accordance with its nature. These "states" are, however, changing. Therefore, in order to discover the source of their movement and the changes they undergo, one should use new notions to grasp the relatively permanent "states" of matter that lie deeper and whose regular movement determines the definiteness of former states. Then, however, treating notions referring to those previous states as absolutely sharp would logically contradict new cognition. We should, therefore, consciously regard them as flexible. (Ładosz 1956, p. 133)

This does not mean, however, that Ładosz rejects formal logic altogether; he states that dialectical logic requires reasoning in accordance with the laws of formal logic. He notes that not all self-contradictory judgments are accurate. As I mentioned above, he does not postulate that a "system of the contradictory logic," "dialectical formal logic," "multiple-valued logic" should take the place of formal two-valued logic; such ideas he associates with Hegel's idealism.

Ładosz's attitude towards Hegel, notwithstanding the remark above, must be called the most favourable out of the philosophers engaging in this discussion. He does, admittedly, write about the necessity of Marxism freeing dialectic from "the mystique of self-movement and self-development of thought" (Eadosz 1956, p. 134), i.e. the tendency to solve contradiction using language alone. Nevertheless, he claims that, in Hegel, we have the first outlines of dialectical logic as well as the critique of formal logic. The main thrust of Ładosz's critique, therefore, is aimed not at Hegel but at Plekhanov and Engels; the errors made by the latter are explained as the result of the historical limitations of his times.

The first person to respond to Ładosz's text was Helena Eilstein in the article "Logika $w$ świetle marksistowskiej teorii poznania" [Logic in light of the Marxist theory of cognition] (Eilstein 1956a; b). Although this was her first publication in the course of the discussion, she had been discussing the subject with Schaff, 
which—as Schaff himself admitted — contributed greatly to the shift of his position. Eilstein (1922-2009) was a Marxist philosopher by nature and a philosopher of science (mostly physics). In the 1950s, she wrote extensively on dialectical materialism, the transition from quantity to quality, theory of reflection and the notion of matter (for a bibliography of her works, see Góralczyk 2010, pp. 85-86). She was in many ways a typical dialectical materialist_working within a realist, materialist, and objectivist framework of diamat and interested in nature more than the social and historical world-but a dialectical materialist characterized by subtlety and originality. Eilstein left Poland after the anti-Jewish campaign of 1968; in her later years, she abandoned Marxism but remained a materialist.

In her text, she accuses Ładosz of vagueness and lack of clarity. Nevertheless, she modified her own position because of his text. She accepted limiting the realm of formal logic to the study of the laws of deductive reasoning-suggested by Ładosz-and stressing the importance of the issue of vague notions (1956a, p. 125). Eilstein describes dialectics as the theory of the struggle and unity of opposites, which, as she argued, can be basically reduced to two theses. The first one postulates the internal dynamic of the world (possible due to the existence of opposing tendencies and their mutual struggle). The second thesis claims that homogeneous elementary objects do not exist.

According to Eilstein, Marxism seems to be the search for opposing tendencies that determine development (1956a, p. 135-137). She describes the development of human knowledge as the result of two opposing tendencies-on the one side, the tendency to increase cognitive data (or the infinite character of human knowledge connected with the infinite complexity of an object) and the tendency to build a system based on a historically limited set of data (or the limited character of concrete knowledge at a certain level of development) on the other. She also suggests that it is possible to enumerate a multitude of other pairs of opposing tendencies involved in human knowledge.

Following Ładosz and Rolbiecki (see below), Eilstein acknowledged the occurrence of logical contradictions in scientific development. Similarly to the latter, she emphasized the necessity to overcome these contradictions. According to her, this is often done through the rejection or restriction of the use of one of the contradicting laws and the modification of the conceptual apparatus (Eilstein 1956a, p. 141). However, she rejects Ładosz's thesis that contradictions connected with movement are everlasting. She claims that the principle of non-contradiction has a universal meaning and openly criticizes Engels' opinion on the subject. In the second part of the text, published in the following issue of the journal (1956b), Eilstein focused on the vagueness of notions and the gradual nature of truth. In our everyday pursuit of knowledge, as well as in science, we often use vague notions and use descriptions which are true only relatively (Eilstein cites many examples, mostly from physics, e.g. classical mechanics). In the course of scientific development, some of the terms are replaced with new, more precise ones and some become restricted in their application, but their employment is, nevertheless, unavoidable. Both of these factors, as Eilstein argues, present a challenge for two-valued logic, which nevertheless proves itself useful and efficient. The aim of Marxist epistemology should be to build a theory which takes the relative 
character of truth into consideration but preserves and explains the bivalence of logic. As she suggests, one of the possible ways to do this is to re-interpret the process of assigning logical value that would make it closer to legitimacy than absolute truth.

Schaff's response to Ładosz's text (1957) reveals his concern about the accusations of revisionism which emerged in response to his position. Almost half of his argument is focused on the dogmatic nature of Ładosz's polemic and on the threat to creative and scientific freedom posed by the rejection of revisionism (both Schaff and Eilstein also felt offended by Ładosz's comments about the banality of their work). In the first part of the text, Schaff accuses Ładosz of being inconsistent in his position, as well as of being vague and "representing views which are widely considered to be obsolete and are not in line with the current stage of the development of logic and philosophy" (Schaff 1957, p. 202).

The general bitter tone of Schaff's answer was understandable: his views were condemned in 1956 in the Soviet Voprosy filosofii. He was criticized there by Mitrofan Alexeev in his text " $O$ dialekticheskoi prirode suzhdenia" [On the dialectical nature of a judgment]. Alexeev was an advocate of dialectical logic. He argues that every elementary proposition contains a contradiction because it expresses the dialectics of identity and difference as well as that of universality and particularity. Besides elementary propositions, there is also a special class of "dialectical propositions." Alexeev describes them as "propositions formulated as a result of applying the dialectic method to the study of reality," which might appear spontaneously "under the influence of the dialectical nature of things and processes" (Alekseev 1956, p. 53). This definition is far from clear, but he names propositions of movement as an example of dialectical propositions and criticizes Schaff's text in exactly this context. Nevertheless, Alexeev claims that the principle of non-contradiction "has no direct relation to the problem of dialectical contradiction" (Alekseev 1956, p. 56). One can assume that he tries to avoid the violation of the principle of noncontradiction, banned by the discussion of 1951 , by introducing a differentiation between attributes and "sides of an object." The principle of non-contradiction, in Alexeev's interpretation, prohibits one from simultaneously assigning a certain attribute to an object and not assigning it, while the dialectical contradictions consist of the "objective (...) existence of two opposed sides of one object that simultaneously assume and exclude each other, in the same respect" (Alekseev 1956, p. 56). His position, as one can see, is deeply connected to Hegelian formulations from The Science of Logic, treated with no thorough examination of Hegel's (nor Marx's) method.

The views of the advocates of dialectical logic (Alexeev and Ładosz, among others) were later analyzed by Maria Kokoszyńska (1957), a logician and epistemologist, one of the important representatives of the second generation of the Lvov-Warsaw School. Kokoszyńska refers to the conclusions of the discussion in Voprosy filosofii from 1951 and opts for understanding the dialectical contradictions as the coexistence of opposing tendencies. Any other solution of the relationship between formal logic and dialectics is merely declaratory and, in fact, violates the requirements of formal logic. Ładosz is a special object of her critique: Kokoszyńska blames him for inconsistency and lack of clarity. Moreover, she considers Ładosz's 
theory of knowledge as pessimistic, tragic and infected with agnosticism, as the concept of eternal contradiction sets very strict limits on human knowledge (Kokoszyńska 1957, p. 144).

Last but not least, one should also remember Waldemar Rolbiecki. ${ }^{6}$ In 1953, he won the first prize in the competition organized by Myśl Filozoficzna with a work devoted to problems of formal logic and Marxism-Leninism. Part of this work was published in Myśl Filozoficzna (Rolbiecki 1955) in the same year as Schaff's revision of his earlier views, but in an earlier issue. Zbigniew Jordan considers Rolbiecki and Ładosz to be advocates of the belief that dialectical contradictions lead to logical contradictions (Jordan 1963, p. 304). However, in contrast to Ładosz, Rolbiecki was an advocate of the universal validity of the principle of non-contradiction. His work contained an exegesis of the ambiguous use of the word "logic" in Marx and Engels and combined the proclamation of universal validity of the principle of noncontradiction with the thesis that the dialectical nature of reality leads to logical contradictions, which play an important role in the development of our knowledge. His position was unique because of this multi-dimensionality, and it therefore seems more appropriate to discuss his views separately. It should be noted, however, that he influenced both Ładosz and Eilstein.

Rolbiecki criticizes Schaff's early concept of the diarchy of two logics, but notices the change in his views in 1951 . He rejects the concept of dialectical logicwhich he understood as a "logic of contradiction" or a multiple-valued logic — and proclaims the universal validity of reasoning in accordance with the laws of formal logic. At the same time, however, he argues that reality is complex, multi-sided and full of contradictions, and because of that, in the real process of the historical development of science, some logical contradictions appear. They play an important part in the development of our knowledge but have to be overcome by introducing new, more precise notions, or specifying the scope of applicability of a certain predicate or theory. However, these new formulations are not everlasting; in the course of history, they will reveal their internal contradictions and be replaced with new ones. This replacement, however, is not something that can be done instantly by means of semantic analysis and agreement on language use alone. It requires further research towards an improved and deeper knowledge of reality. Conflicts with the principle of non-contradiction are neither something everlasting and absolute nor illusory and easy to eliminate. Two-valued logic is universal, although some reformulations of what the logical value is - treating it as something less absolute and formal-might be needed to bring it closer to the real process of human thinking and the history of science.

\footnotetext{
${ }^{6}$ Waldemar Rolbiecki's (1927-2002) research interests focus mostly on scientific forecasting and pedagogy. His Master's degree was devoted to scouting, and he wrote extensively on the history of education in Poland (Skarbek 2003).

7 This rejection of dialectical logic was criticized as a fundamental mistake in Voprosy filosofii by A. P. Ermilov (1956, p. 185). Ermilov, however, understood dialectical logic as broader than Rolbiecki.
} 


\section{Two notions of science: a postscript from Evald Ilyenkov}

Schaff's rejection of dialectical contradiction was criticized not only by Jarosław Ładosz. It is mentioned also in Evald Ilyenkov's article "Vershina, konets i novaia zhizn' dialektiki (Gegel' i konets staroi filosofii)" [The Peak, The End and the New Life of Dialectics (Hegel and the End of Old Philosophy)], which can be treated as a kind of postscript to the whole discussion. ${ }^{8}$ This article is noteworthy, as it shifts the center of attention from the principle of contradiction towards the problem of truth and science-an issue hidden in the Polish discussion but crucial for understanding the real philosophical conflict behind the ostensible scholasticism.

As Ilyenkov argues, Schaff postulates the "purification" of historical materialism from dialectics and contradiction, because those Hegelian relicts cannot conform to the requirements of "science." His understanding of science, however, is a positivist and neo-positivist one, not a Marxist one. Schaff treats science not as a real historical process but as a static, coherent system, "only a 'sign system,' a system of 'terms' and "statements," built in accordance with a number of pre-established rules, including, of course, the "exclusion of contradiction"" (Ilyenkov 1991, 134). $\mathrm{He}$ is a revisionist who does not understand the organic unity of historical materialism and materialist dialectics as two aspects of the same method. He does not understand the Marxist method, which for Ilyenkov meant a lack of understanding of Marx's analyses of social reality.

I am convinced that understanding truth as an organic and historically evolving system, a certain totality in motion, was the real issue at stake in polemics with Schaff's Marxism not only for Ilyenkov, but also for Ładosz. Nevertheless, the opposition of those two alternative ways of thinking about knowledge- one synchronic and concerned with consistency and precision, the other historical and focused on contradiction and development-was in the Polish case deeply buried under debates over Zeno's paradoxes. The argumentation based on them was a part of Engels' philosophy of nature, which was crucial for the tradition of dialectical materialism. Even though Ilyenkov and Ładosz criticized diamat, they were immersed in this tradition of thought and inherited many of its problems and aporiae. This is partly connected to Lenin's complicated legacy, which to this day provokes discussions on its relationship with the framework of dialectical materialism (cf., e.g., Coombs 2016; Mareev and Mareeva 2018).

\section{Conclusions}

Although Ładosz (with the help of Rolbiecki) convinced Eilstein to take into consideration the history of science, the historical and Praxis-oriented line remained in a minority. The rejection of a logical interpretation of dialectical contradiction in the

\footnotetext{
8 This is the edited version of a paper for the Hegel Congress in 1974, in which Ilyenkov was unable to participate (see Ilyenkov 1991, p. 452). It was published in 1991, as he struggled with censorship throughout the 1970 s.
} 
discussion was possible because of the well-established role of the Lvov-Warsaw School, combined with the relative freedom of philosophical investigations, as well as the very short term of Stalinism. The school—despite all the damage it suffered during the war and in the first decade after - was still well organized and influential, and this influence was decisive in establishing the criteria of scholarly debate. The change in the situation of formal logic in the Soviet Union also played a part in the victory of formal logic (cf. Jordan 1963, p. 300).

The significance of the discussion for the development of Polish Marxism lies not in the rejection of the logical understanding of dialectical contradiction among most Marxists but in the shift in Schaff's position-coming under the influence of the Lvov-Warsaw School in establishing the criteria of scholarly debate and the methods of solving philosophical problems. Considering the intellectual and institutional role he played and the fact that he was-beyond any doubt-the most influential Marxist philosopher in Poland, it was a very important factor in the development of the intellectual landscape. The overlap of Marxism and the analytical tradition gave rise to Schaff's semantic studies (Wstęp do semantyki [Introduction to Semantics] 1960, Język a poznanie [Language and Cognition] 1964). The influence was reflected in works by Władysław Krajewski, concerned mainly with the problems of epistemology. Later, it contributed to the emergence of the Poznan Methodological School in the 1960s. The members of the school (among the most important being Leszek Nowak, Jerzy Kmita, Jan Such and Jerzy Topolski) focused mainly on epistemological and methodological problems and tried to incorporate analytical tools into Marxism. Unlike other Revisionist currents, they rejected the more humanistic approach to Marxism and instead built their identity on scientism.

These phenomena allow Henryk Skolimowski to even speak of the "analyticallinguistic Marxism" in Poland (Skolimowski 1965). Although the combination of Marxism and analytic tools also happened in the West in the 1980s (to name just one example, G. A. Cohen), the appearance of it in Poland in the 1960s and the role it played must be called exceptional. One can also speculate that it was this specific intellectual atmosphere that resulted in the relative absence of Hegel from Polish Marxism. With some notable exceptions, e.g. Tadeusz Kroński and, much later, Marek Siemek, ${ }^{9}$ Polish Marxists were rather suspicious if not hostile towards the Hegelian legacy. The struggle towards clarity and methodological rigidity made Hegel a rather difficult ally (cf. Jordan 1961, p. 95).

Finally, the emphasis on historical praxis allows one to recognise that "dialectical logic" can be interpreted as two different philosophical projects: either as a certain "logic of contradiction" that should construe new formal laws of reasoning, or as a discipline that describes the principles of thinking in the process of the development of knowledge. The latter interpretation was often associated with the abovementioned anti-Positivist, history- and praxis-oriented line in Marxism and the methodological approach inspired by Lenin's Philosophical Notebooks. Those two meanings are sometimes difficult to distinguish in the works of the advocates of dialectical

\footnotetext{
9 To some extent, this does not apply to Bronisław Baczko and Marxist aestheticians, especially Stefan Morawski.
} 
logic, but contrasting them allows us to understand the differences between early Schaff and Ładosz or between Mitrofan Alexeev and Ilyenkov.

A thorough reconstruction of the discussion helps us go beyond the label of broadly understood Marxism-Leninism and see that it involved various understandings of Marxism and dialectics. Eilstein and early Schaff were both dialectical materialists: Schaff in a more Stalinist and dogmatic manner, Eilstein in a more creative way. Ładosz was an orthodox Leninist inspired by Philosophical Notebooks, ${ }^{10}$ who in some regards clearly distanced himself from diamat and emphasized the role of history and praxis. A careful examination of the discussion renders visible a conflict that, although hidden, gave life to it. It was the conflict of two opposing models of rationality: one that emphasizes the coherency and precision of the "synchronic" system of knowledge, and one that treats it as a historically evolving contradictory totality in constant movement.

\section{Declarations}

Conflict of interest The author declared that there is no conflicts of interest.

Open Access This article is licensed under a Creative Commons Attribution 4.0 International License, which permits use, sharing, adaptation, distribution and reproduction in any medium or format, as long as you give appropriate credit to the original author(s) and the source, provide a link to the Creative Commons licence, and indicate if changes were made. The images or other third party material in this article are included in the article's Creative Commons licence, unless indicated otherwise in a credit line to the material. If material is not included in the article's Creative Commons licence and your intended use is not permitted by statutory regulation or exceeds the permitted use, you will need to obtain permission directly from the copyright holder. To view a copy of this licence, visit http://creativecommons.org/licen ses/by/4.0/.

\section{References}

Ajdukiewicz, K. 1948. Zmiana i Sprzeczność. Myśl Wspótczesna 8-9: 35-53.

Alekseev, M.N. 1956. O dialekticheskoi prirode suzhdenia. Voprosy Filosofii 2: 49-61.

Beseda s V.M. Mezhuevym 2014, Voprosy filosofii, 2. Retrieved from: http://vphil.ru/index.php?option= com_content\&task=view\&id=901.

Coombs, N. 2016. Did Lenin Refound Marxist Dialectics in 1914? The European Legacy 21 (1): 1-18. https://doi.org/10.1080/10848770.2015.1085676.

Czakon, T. 1998. Dogmatyzm i Polityka. Nowa Krytyka 9: 125-126.

Eilstein, H. 1956a. Problem logiki w świetle marksistowskiej teorii poznania (cz. I), Myśl Filozoficzna, 5, 124-150.

Eilstein, H. 1956b. Problem logiki w świetle marksistowskiej teorii poznania (cz. I), Myśl Filozoficzna, $6,116-132$.

Ermilov, A. 1956. Razrabotka problem marksistko-leninskoj filosofii v Pol'she. Voprosy Filosofii 1: $179-187$.

Góralczyk, M. 2010. Lista publikacji profesor Heleny Eilstein. Filozofia Nauki 18 (2): 85-92.

Ilyenkov, E. 1991, Vershina, konets i novaia zhizn' dialektiki (Gegel' i konets staroi filosofii). In Filosofiia i kul'tura (pp. 115-141). Moskva: Politizdat.

10 On Ładosz's reading of Lenin's Philosophical Notebooks, see (Ładosz 1961). 
Jordan, Z. 1961. The Development of Philosophy and Marxism-Leninism un Poland since the war. In Studies in Soviet Thought, ed. J.M. Bocheński and J.D. Blakeley, 88-100. Dordrecht: D. Reidel Publishing Company.

Jordan, Z. 1963. Philosophy and ideology: the development of philosophy and marxism-leninism in Poland since the Second World War. Dordrecht: D. Reidel Publishing Company.

K itogam obsuzhdeniia voprosov logiki 1951, Voprosy filosofii, 6, 143-149.

Kojkoł, J. 2009. Polskie spory filozoficzne w latach 1945-1949. Zeszyty Naukowe Akademii Marynarki Wojennej 4 (179): 101-144.

Kokoszyńska, M. 1957. Krytyka niektórych poglądów na stosunek logiki do dialektyki. Studia Filozoficzne 3: 118-151.

Ładosz, J. 1956. O sprzecznościach logicznych i dialektycznych. Myśl Filozoficzna 4: 106-135.

Ładosz J. 1961. Metodologiczne znaczenie "Zeszytów Filozoficznych” Lenina dla rozwoju marksizmu w Polsce. In Dialog o filozofii marksistowskiej (pp. 11-107). Warszawa: Książka i Wiedza.

Lenin, V. I. 1972. Collected Works. Vol. 38 (Philosophical Notebooks). Translated by C. Dutt. Moscow: Progress Publishers.

Lobkowicz, N. 1959. Das Widerspruchsprinzip in der neueren sowjetischen Philosophie. Dordrecht: D. Reidel Publishing Company.

Lobkowicz, N. 1961. The principle of contradiction in recent soviet philosophy. Studies in Soviet Thought 1: 44-51.

Mackiewicz, W. (Ed.) 2001. Polska filozofia powojenna. 1. Warszawa: Agencja Wydawnicza Witmark.

Mareev, S., Mareeva E. 2018. Hegelian Dialectics and Soviet Marxism (from Vladimir Lenin to Evald Ilyenkov). In A. Bartonek, E. Burman (Eds.). Hegelian Marxism The Uses of Hegel's Philosophy in Marxist Theory from Georg Lukács to Slavoj Žižek (pp. 61-80). Stockholm: Elanders.

Mervart, J. 2013. Filosofický časopis mezi stalinismem a normalizací. In P. Dvořák, L. Kvasz, P. Urban, J. Velek, J. Zumr (Eds.). 60 let Filosofického časopisu (pp. 9-32). Praha: Filosofia.

Nowaczyk, J. 1967. Z dyskusji o zasadzie sprzeczności w polskiej literaturze filozoficznej ostatnich lat. Studia Philosophiae Christianae 3 (1): 301-305.

Ossowski, S. 1947. Doktryna marksistowska na tle dzisiejszej epoki. Myśl Współczesna 12 (19): 501-513.

Ossowski, S. 1948a. Teoretyczne zadania marksizmu. Myśl Wspótczesna 1: 3-19.

Ossowski, S. 1948b. Na szlakach marksizmu. Myśl Wspótczesna 8: 19-45.

Protiv putanitsy i vul'garizatsii v voprosakh logiki 1955, Voprosy filosofii, 3, 158-171.

Rolbiecki, W. 1955. Niektóre zagadnienia logiki formalnej w świetle teorii marksizmu- leninizmu. Myśl Filozoficzna 2: 43-78.

Schaff, A. 1946. Zasada sprzeczności w świetle logiki dialektycznej. Myśl Wspótczesna 3-4: 328-353.

Schaff, A. 1948. Marksizm a rozwój nauki. Myśl Wspótczesna 6-7: 245-264.

Schaff, A. 1955. Dialektyka marksistowska a zasada sprzeczności. Myśl Filozoficzna 4: 143-159.

Schaff, A. 1950. Wstęp do teorii marksizmu (5th Ed.). Warszawa: Spółdzielnia Wydawnicza "Książka."

Schaff, A. 1951. Z zagadnień marksistowskiej teorii prawdy. Warszawa: Ksiązka i Wiedza.

Schaff, A. 1952. Poglady filozoficzne Kazimierza Ajdukiewicza (Szkic krytyczny), Warszawa: Książka i Wiedza.

Schaff, A, 1957. Jeszcze raz o dialektyce i zasadzie logicznej sprzeczności, Studia Filozoficzne, 1, 201-213.

Skolimowski, H. 1965. Analytical-Linguistic Marxism in Poland. Journal of the History of Ideas 26 (2): 235-258. https://doi.org/10.2307/2708230.

Stępień, A. B. 1990. Rys rozwoju filozofii marksistowskiej i problem dialogu filozoficznego z marksizmem od roku 1945. In: A. B. Stępień (Ed.). Wobec filozofii marksistowskiej. Polskie doświadczenia (pp. 21-36). Lublin: TN KUL.

Walicki, A. 1997. Moralne wątpliwości co do "moralnych rozliczeń.” Znak 12: 73-85.

Wiśniewski, T. R. Hegel Adama Schaffa. In M. Woźniak, T. R. Wiśniewski (Eds.). Recepcja myśli Hegla $w$ Europie Środkowej $i$ Wschodniej (pp. 225-239). Warszawa: Ośrodek Badań Filozoficznych. Retrieved from http://obf.edu.pl/wp-content/uploads/2019/06/Recepcja-my\%C5\%9Bli-Hegla.pdf)

Wolenski, J. 1992. Philosophy inside communism: the case of Poland. Studies in Soviet Thought 43 (2): 93-100.

Publisher's Note Springer Nature remains neutral with regard to jurisdictional claims in published maps and institutional affiliations. 